\title{
Optimization of the sustainable professional development program to improve islamic education teachers' performance
}

\author{
Supiana Supiana, Department of Islamic Education, UIN Sunan Gunung Djati Bandung, Indonesia, \\ supiana@uinsgd.ac.id \\ Elih Yuliah, Ministry of Religion, Sukabumi District, Indonesia
}

\begin{abstract}
This study aims to identify the objectives of optimization and produce a new optimization program regarding the Islamic Education Teachers' Continuous Professional Development Program. Besides, this research will also analyze the success of Islamic education researchers' competence in the program. The research method used in this research is Research and Development. Data analysis in this study used qualitative and quantitative analysis. The results showed that the Professional Development Program could improve the competence of Islamic education teachers. The t-test calculation confirms this is greater than the t table as many as 2.43 points. This quality achievement shows that supervisors' training and mentoring in the Professional Development Program context to Islamic education teachers show promising results.
\end{abstract}

Keywords: Islamic education teacher, professional development, teacher's performance.

Received: 02.11.2020 Accepted: 17.12.2020 $\quad$ Published: 10.01.2021

\section{INTRODUCTION}

The implementation of Islamic Religious Education in schools is currently considered less successful in managing students' religious attitudes and behavior and building national morals and ethics. The indicators of the weakness inherent in the implementation of religious education in schools can identify as follows: 1) Islamic Education is less able to change cognitive religious knowledge into "meaning" and "value," or it does not encourage the inspiration of religious values that need to internalize in participants students; 2) Islamic Education cannot work together and cooperate with non-religious education programs; 3) Islamic Education lacks relevance to social changes that occur in society or lacks an illustration of the socio-cultural context (PITA, 2018).

The low level of teacher professionalism cannot separate from several surrounding factors. Ani M Hasan once put forward this view, who stated that the factors causing the low level of teacher professionalism include: 1 . There are still many teachers who do not pursue their professions as a whole. This fact because many teachers work outside of their working hours to fulfill their daily needs so that they do not have time to read and write; 2) Lack of teacher motivation in improving self quality because there is no obligation to research (Dasuki, 2010).

After conducting a simple survey in the field, only a few Islamic education teachers who have mastered ICT are only a few. This data obtained when the Ministry of Religion held an ICT-based Islamic Religious Learning Contest. Participants consisted of 450 Islamic teachers from Primary school until high school. Only 12 people participated in the competition. This phenomenon shows that the level of quality and professionalism of Islamic Religious Education Teachers in Sukabumi City is still low. Based on the results of an orientation study at the Ministry of Religion of the City of Sukabumi, the Section of Islamic Religious Education and the Supervisor of Islamic Religious Education on December 27, 2016, information was obtained about the real conditions of the problems related to the teaching staff of Islamic Religious Education Teachers in public schools in Sukabumi City. Among them are:

[1] There are many teachers in public schools and private-public schools who have passed the competency test in the certification program, especially Civil servant Islamic Religious Teachers, but their performance has not been maximized and is more successful for non-civil servant teachers;

[2] The diversity of teacher competencies in the learning process;

[3] The guidance carried out by school principals and supervisors does not reflect specific aspects of need;

[4] Inadequate teacher welfare.

[5] Academic qualifications that are not relevant to teaching eligibility.

[6] Lack of self-awareness motivates teachers to make changes, especially in the learning process;

[7] many teachers have been certified but have not shown good performance;

[8] teachers' poor work ethic. 
[9] Non-civil servant continuous professional development is more successful than Civil Servant teachers.

These problems illustrate the weak performance of teachers. A certified Civil servant Islamic Religious Education teacher should realize better Sustainable Professional Development performance than non-civil servants teachers. Related to the phenomena described, the problems in this research include: 1) the competence of teachers in compiling scientific papers in the form of scientific publications; 2) the manifestation of low professional competence; 3) Weak teacher performance; 4) Continuous professional development has not shown maximum results; 5) Weaknesses in the development of learning as an aspect of pedagogical competence; 6) So far, training activities or programs organized by the government and those carried out independently of teachers regarding Classroom Action Research for teachers are still lacking; 7) Classroom Action Research training for teachers carried out so far are still dominant at the level of theory or concept, not many are practical; and 8) the ineffective development of the Education and Culture Office, the Teacher Working Group, and the school in managing and implementing Sustainable Professional Development teachers.

\section{METHODS}

Research and Development, according to Gay (Gay, 1980; MABRY, 1981), is an effort or activity to develop a useful product, and not to test the theory. Meanwhile, according to Borg and Gall, R\&D is a research model used to design new procedures and products, which are then systematically field-tested, evaluated, and refined until they meet specific criteria of effectiveness, quality, or the same standard (Gall, Borg, \& Gall, 1996). Meanwhile, according to Nana Syaodih Sukmadinata (Sudjana, 2000), it is an effort to develop a compelling product and not a test theory.

The five stages of this research R\&D include (1) preliminary studies, (2) development of teacher program optimization models and due diligence, (3) limited field trials, (4) validation, and (5) reporting. The research subject is Islamic teacher for Civil Servants at Elementary Schools in Sukabumi City. Initial data for online testing were 67 people. As for the Sustainable Professional Development program for Islamic Religious Education, there were as many as 20 people. Data collection in this study used observation, interview, and documentation techniques. Qualitative analysis is carried out by describing qualitative data information. The qualitative data referred to is data obtained from observations/interviews, FGD activities, and suggestions from consultations with experts. Quantitative analysis was carried out on data obtained from respondents' responses through questionnaires, testing test instruments, and test results. The results of the questionnaire were analyzed using the item summated scales analysis approach from a Likert scale.

\section{RESULTS AND DISCUSSION}

The Sustainable Professional Development model for Islamic Religious Education teachers is designed with several specific procedural and conceptual aspects (presentation material). Islamic Education Teachers at the Elementary School level carry out self-evaluation as an effort to map initial competencies. This selfevaluation design using the Microsoft Excel application to present some of the core competencies of Islamic Religious Education teachers, primarily based on the Decree of the Minister of Religion Number 211 of 2011 concerning National Standards for Islamic Religious Education in Schools. Assessors for the Sustainable Professional Development Program, in this case, the closest unit is the Pokjawas or personal Islamic Religious Education Supervisor according to the level of the academic unit. The analysis of this assessment is directed at preparing teacher profiles based on the initial assessment of Islamic Religious Education. Researchers, assessors for Teacher Performance Appraisals, and Teacher Deliberations for Islamic Education Subjects at each level of the education unit prepare a Sustainable Professional Development planning program. The Islamic Religious Education teacher implements Sustainable Professional Development following the initial assessment's achievement, which describes the Islamic Religious Education teacher's profile. Researchers and Teacher Performance Appraisals (supervisors of Islamic Education) carry out monitoring of the implementation of Sustainable Professional Development results. Teacher Performance Appraisal Appraisers carry out a performance appraisal at the end of the year, according to the education unit level.

Self-evaluation design using an application that can be filled in directly by the teacher. This application also designs with continuous data entry in each program window. The use of hyperlinks makes it easier for Islamic Religious Education teachers to fill in any data needed for self-evaluation. The achievement of the value of the Islamic Education Teacher Competency Assessment uses to compile teacher profiles. The assessor shall inform the teacher who is testing the importance of the Teacher Competency Assessment in the form of this self-assessment based on proof of records for each competency. 
Researchers also compile a competency mapping design for mapping teacher profiles. The competency mapping contains knowledge questions related to the six competencies of Islamic Religious Education teachers based on the Decree of the Minister of Religion Number 211 of 2011. The accessibility of filling this competency adopts the system used by the Division within the Ministry of Religion through the Sustainable Professional Development Team for Islamic Religious Education. Competency mapping using the Adobe Flash Version 11 tool.

The trial phase begins with the product developed in this study through a development procedure. The readability test of the Sustainable Professional Development model carries out through the Forum Group Discussion (FGD) at the Subject Teacher Deliberation and the expert and practitioner legibility test. This trial was conducted through a descriptive method, produced descriptive data, analyzed, and used to revise the draft model (conceptual model). The field results show that the Sustainable Professional Development model is quite good and has reasonably easy readability. The use of IT considering to facilitate Islamic Education teachers in filling out the instruments. From 20 Islamic Religious Education teachers in Elementary Schools get a high distribution of scores. The scores obtained range from 18 to 20 . This indicates a high response in the $80 \%$ to $100 \%$ range. In this respect, their response to this test tool was considered favorable.

The Sustainable Professional Development Program for Islamic Religious Education teachers in Sukabumi City is related to Permenegpan and Bureaucratic Reform Number 16 of 2009. In these two regulations, Sustainable Professional Development is developing teacher competencies that are carried out according to needs stages and is sustainable in increasing professionalism.

This is reinforced by the management of the Islamic Religious Education Subject Teacher Council in Sukabumi City that the Sustainable Professional Development of Islamic Religious Education teachers is carried out to create professional teachers and develop students' interests and talents following their fields of mastering Islamic Religious Education. The aim of the Sustainable Professional Development program for Islamic Religious Education teachers is in line with competency development, which is strengthened by a character-based development pattern by dynamizing the three main character pillars, namely excellence, passion, and ethics.

Excellence means that Islamic Religious Education Teachers must have certain advantages in their fields and world by a). Commitment or purpose, which is committing to always be in the corridor of goals in carrying out activities to achieve excellence. b). Opening self-gift or ability, which is having the ability to find self-potential. C). Being the first and the best can be, namely having a strong motivation to be the first and the best in their field. d). Continuous improvement, namely making continuous improvements.

Passion for professionalism, namely the strong will of the Islamic Religious Education Teacher who intrinsically animates all professional patterns, namely: a) Passion for knowledge, namely the spirit to always increase knowledge through formal or informal means. b) Passion for business, namely the spirit to do correctly in carrying out its business, duties, and missions. c). Passion for service, namely the spirit to provide the best service for his responsibility. d) Passion for people, namely the spirit to realize service to others based on humanity.

Ethical or ethics that is manifested in character and the primary foundation for the realization of professionalism, namely: a) Trustworthiness, namely honesty or being trusted in the whole personality or behavior b). Responsibility, namely responsibility for himself, his professional duties, family, institutions, nation, and towards Allah. c) Respect, namely the attitude of respecting anyone who is directly or indirectly related to their profession d) Fairness, namely responsibility for themselves, their professional duties, family, institutions, nation, and towards Allah SWT. e) Fairness, namely carrying out duties consistently in accordance with applicable regulations g) Care, which is full of concern for various matters related to his professional duties f) Citizenship, which is to become a citizen who understands all his rights and obligations and embodies them in his professional behavior.

The objectives developed are under the spirit of Permenegpan and Bureaucratic Reform Number 16 of 2009 and Decree of the Minister of Religion Number 211 of 2011 concerning Guidelines for the Development of National Standards for Islamic Education in Schools. This goal also intersects with the Ministry of Education and Culture's version of the Sustainable Professional Development Guide for Teachers, which is to improve the quality of education services in schools/madrasahs to improve education quality. Meanwhile, the specific objectives include: 1) facilitating teachers to continuously update competencies that are demanded in the future concerning their profession; 2) motivating teachers to be committed to carrying out their primary duties and functions as professionals; 3) promote the image, dignity, and dignity of the teaching profession, respect, and pride for teachers.

Government Regulation Number 55 of 2007 states that the management of religious Education and Religious Education is under the Ministry of Religion of the Republic of Indonesia. As the Ministry of Religion manager, the Ministry of Religion is obliged to guarantee the quality of Religious Education in 
schools. In the context of implementing quality Islamic Religious Education and the needs of the community, the Ministry of Religion needs to develop the eight National Education Standards established by the National Education Standards Agency.

The Sustainable Professional Development Program is carried out by the Regional Office of the Ministry of Religion of the Republic of Indonesia. Sukabumi City is one of the targets. This resource person is a team appointed by the Directorate of Islamic Religious Education, Ministry of Religion. This phenomenon shows that internally, the Office of the Ministry of Religion of Sukabumi City c.q. The Islamic Religious Education Section does not yet have an independent program regarding the Sustainable Professional Development of Islamic Religious Education teachers.

The Sustainable Professional Development Program in Sukabumi City has only become one of the targets of several pilot projects of the Ministry of Religion Directorate. Likewise, the Sustainable Professional Development program for Islamic Religious Education from the perspective of the Directorate of Islamic Religious Education at the Ministry of Religion has only become one of the priority programs for Islamic Religious Education in 2017. After one year, 2018, structurally, there has been no further development.

Supervisors mostly carried out the optimization of the Sustainable Professional Development program for Islamic Religious Education with various activities related to improving learning quality and encouraging scientific publications. The Islamic Religious Education Section of Sukabumi City aligns the Sustainable Professional Development program of Islamic Religious Education following the Directorate of Islamic Religious Education's program.

Phenomena in the field indicate that there are no strategically designed programs in the context of Sustainable Professional Development. Quality development is mostly carried out at the school level and the Teacher Working Group, the involvement of the supervisor of Islamic Religious Education, and several workshop activities under the auspices of the DIPA of the Islamic Religious Education Section of the Ministry of Religion, Sukabumi City.

Supervision of the supervisor of Islamic Religious Education under their respective primary duties and functions continues. The Islamic Religious Education Supervisor, in this case, carries out the planning, process, and evaluation of academic supervision on Islamic Religious Education learning. This activity is carried out continuously following the supervision schedule. However, when connected with the development of the Sustainable Professional Development of Elementary School Islamic Religious Education teachers, until 2017, it has not looked massive. The Sustainable Professional Development Program for Islamic Religious Education teachers, although the Education Office appoints personnel, their guidance is still directed at the Indonesian Ministry of Religion, in this case, the Islamic Education Section of the City of Sukabumi. This authority is in line with the mandate of Government Regulation Number 55 of 2007 concerning Religious Education and Religious Education

Development of Islamic Religious Education Teachers in Sukabumi Regency begins with a Performance Evaluation and Competency Mapping. Although not yet fully implemented by teachers, their response to this activity is considered acceptable. The Sustainable Professional Development design for Islamic Religious Education is different from the Sustainable Professional Development for other teachers. In other teachers, massive involvement emerged from the Education Quality Assurance Agency, the Education Office, and the Teacher Working Group and the Subject Teacher Council. Meanwhile, for Islamic Religious Education teachers, this design was adopted from the program of the Directorate of Islamic Religious Education of the Ministry of Religion of the Republic of Indonesia, which did not involve elements of the Education Quality Assurance Agency and the Education Office, but rather involvement at the Teacher Working Group stage and the Subject Teacher Council, Islamic Religious Education Section at the Ministry. The religion of Sukabumi City, also Supervisor of Islamic Religious Education.

This evaluation is concerned with examining the results as the Islamic religious education objectives are most frequently carried out in almost all evaluation models. The difference can be categorized into models that prioritize learning outcomes (changes in behavior) and those focusing on specific program objectives. The models are the Tylerian model, the learning evaluation model, the program's specialpurpose model.

The Sustainable Professional Development Program implemented in Sukabumi City refers to the theoretical aspects developed in Permenagpan and RB Number 16 of 2009 concerning Teacher Functional Positions and Decree of the Minister of Religion Number 2112011 concerning Guidelines for the Development of National Standards for Islamic Religious Education in Schools.

The assumptions developed in implementing this program are under Permenagpan, and RB Number 16 of 2009 concerning Teacher Functional Positions, when analyzed, can be described as follows:

a. Education is a very strategic process in educating the nation's life, so it must be done professionally. Therefore, the teacher, as one of the actors of Education, must be a professional. Thus the existence of 
teachers in the educational process can be meaningful for society and the nation. The teacher's meaning for the community will lead to a better appreciation from the community for the teacher.

b. Teachers are expected to participate in national development to realize Indonesian people who are devoted to God Almighty, excel in science and technology, and have an aesthetic, ethical, noble character and personality. It is not an exaggeration to say that the future of society, nation, and state is primarily determined by teachers. Therefore, according to the teacher's functional position, the teaching profession needs to be developed remarkably and proportionally.

c. The duties and functions inherent in the teacher's available position are carried out according to the applicable rules. Thus, it is necessary to evaluate the implementation of the teacher's duties and obligations in carrying out learning/guidance or additional tasks relevant to the school/madrasah's function. This assessment is carried out to ensure a quality learning process at all levels of education.

d. To assess teachers' ability to apply all competencies and skills required in the learning process, mentoring, or the implementation of additional tasks relevant to the school/madrasah function. Thus, teacher performance profiles as a description of teacher strengths and weaknesses will be identified and interpreted as a needs analysis or skills audit for each teacher, which can be used as a basis for planning Sustainable Professional Development.

Evaluation of the Sustainable Professional Development program is directed at several things. First, the theoretical aspects that form the foundation of development. Second, design planning for the Sustainable Career Learning initiative. Third, the design of Islamic Religious Education's Sustainable Professional Growth. Fourth, the Sustainable Professional Development of Islamic Religious Education, especially for teachers of the Sustainable Professional Development program of Islamic Religious Education, was not fully implemented, especially in developing the second to eighth program. The analysis of this is as follows.

a. The Sustainable Professional Development Program for Islamic Religious Education in Sukabumi City awaits development from the center. This causes delays in implementation at the local level. This fact is supported by the fact that this program from the perspective of the Directorate of Islamic Religious Education, especially from 2017 to 2018, is still at the piloting and training stages for core trainers at every level at the central, provincial, and district/city levels.

b. Pedagogic development I, namely learning planning, is the supervisor's initiative after implementing online Competency Assessment and central training at the provincial level involving teachers and supervisors of Islamic Religious Education. Participants involved include teachers and supervisors of Islamic Religious Education in Sukabumi City. This fact shows that the Islamic Religious Education Teacher's Sustainable Professional Development training program has not yet entered the implementation stage for direct teachers, but core trainers.

c. The development of the second to eighth programs, which include professional training for the preparation of research and books, has not yet been carried out. This non-implementation is influenced by central programs that have not addressed this indirect training on Islamic Religious Education teachers' target.

The Sustainable Professional Development Program for Islamic Religious Education needs to be facilitated by budgeting in its implementation. In the context of the Islamic Education Section of Sukabumi City, the budgeting for the Sustainable Professional Development of Islamic Religious Education has not yet appeared to materialize, especially in the 2017 and 2018 fiscal years (when this research was conducted). The Learning Planning Training activities are carried out through the supervision of Islamic Religious Education supervisors, especially in Islam's academic supervision at the Elementary School level in Sukabumi City.

Based on the above research results, can be explained some of the advantages and limitations of the Sustainable Professional Development program for Islamic Religious Education Teachers in Sukabumi City, especially for Elementary School Islamic Religious Education Teachers. The advantages of this program are:

a. The teacher's response to this program is quite good. They think that this will only be implemented in a structured manner for Islamic Religious Education teachers per the DITPAI program of the Indonesian Ministry of Religion.

b. Expansion in the scope of areas of instructor competence. For Islamic Religious Education teachers, other competencies, namely spirituality, and leadership strengthen teachers' position in the relationship between duties and responsibilities as an educator. This competency is not found in other teachers. The Decree of the Minister of Religion Number 211 of 2011 has good reasons that differentiate Islamic Religious Education teachers from other teachers. Islamic Religious Education teachers must have advantages over other teachers. It aims to create a religious culture in schools. 
c. The Sustainable Professional Development Program for Islamic Religious Education teachers has been using IT tools capable. The use of this tool makes it easier for teachers to do self-evaluation and competency mapping. In other teachers, this tool has not been found massively in the field.

d. There are still many Islamic Religious Education teachers who cannot use IT tools smoothly as for limitations. This fact is especially the case for older Islamic Religious Education teachers. This condition encourages the Sustainable Professional Development of Islamic Religious Education developers to train teachers technically in applying IT tools.

e. Support from the technical development of the Sustainable Professional Development of Islamic Religious Education tends to be weak. This weakness can be indicated by the weak strengthening of the Sustainable Professional Development Policy for Islamic Religious Education from the Islamic Education Section of the Office of the Ministry of Religion, Sukabumi City, as well as technical operations in the Teacher Working Group and the Council of Teachers for Islamic Education Subjects.

f. The involvement of school principals tends to be weak. Principals tend to monitor and develop the Sustainable Professional Development of other teachers, while Islamic Religious Education teachers are less touching. Schools are the closest unit for Islamic Religious Education teachers in developing their professional development plans.

This research is more likely to lead to the Sustainable Professional Development planning model for Islamic Religious Education teachers. It has not touched directly on the experience of implementing the Sustainable Professional Development for Islamic Religious Education teachers after compiling plans based on evaluation competency mapping. This weakness is reinforced by the fact that the Sustainable Professional Development of Islamic Religious Education teachers is still in the application stage of selfevaluation and competency mapping. The implementation stages, especially training related to Islamic Religious Education teachers' competency aspects, have not been implemented. Likewise, this assumption strengthened that the Sustainable Professional Development of Islamic Religious Education teachers' implementation period is a long time needed during the promotion and teacher positions.

Not all of the Sustainable Professional Development Program for Islamic Religious Education teachers in Sukabumi City went smoothly. Implementing the Sustainable Professional Development program for Islamic Religious Education teachers is still ongoing at the self-evaluation and competency mapping stages. In terms of developing the competence of the Islamic Religious Education teacher, several strategies can be carried out, namely:

a. The Sustainable Professional Development of Islamic Religious Education teachers needs to involve other stakeholders such as the Principal as the closest leader of teachers in their schools and coordination with the Education Office as a supervisory agency for Islamic Religious Education teachers appointed by the Regional Government.

b. Coaching and professional development of teachers are oriented towards research programs, ability testing, implemented collegially, focuses on teacher participation, and helps teachers who are considered weak in some aspects of competence.

c. The development of teacher professionalism is a global concern because teachers have a duty and role in providing information on science and technology and forming attitudes and a spirit that can survive.

d. The professional development of Islamic Religious Education teachers is carried out by observing the environment. In this connection, bureaucratic factors, especially the education bureaucracy, are often insufficient/unsupportive of creating an atmosphere conducive to teaching staff's professional development.

e. It is necessary to develop an appropriate strategy in an effort to create a conducive climate for the professional development of Islamic Religious Education teachers.

f. Strategies that can be developed in teacher professional development include 1) A paradigm shift strategy. This strategy begins by changing the bureaucratic paradigm to develop itself as a serviceoriented institution, not served; 2) Debureaucratization strategy. This strategy is intended to reduce the level of bureaucracy that can hinder the self-development of educators.

g. The professional development of Islamic Religious Education teachers is directed at developing innovation. This innovation will have a positive impact on professional development.

h. The development of the Sustainable Professional Development program for Islamic Religious Education teachers to strengthen teacher professionalism can be carried out in special training stages. This type of training is carried out in authorized training institutions. Special training is provided based on special needs or due to new developments in particular science.

i. Professional training for teachers of Islamic Religious Education can also involve universities or other educational institutions. This is intended to improve teachers' abilities in several abilities, such as conducting classroom action research, compiling scientific papers, planning, implementing, and evaluating learning, etcetera. 
j. In the context of the Islamic Religious Education teacher's professional development, the Principal can carry out internal school coaching under the Islamic Religious Education Supervisor's direction.

k. Regular activities can identify Islamic Religious Education teachers' weaknesses in discussing educational issues with discussion topics according to school problems.

Islamic Religious Education teachers' professional development, even though they are designed with a good program, adopting the Sustainable Professional Development program of Islamic Religious Education in DIPAI Religion of the Republic of Indonesia, will not be optimal if the teacher cannot develop creativity. The development of this creativity is one of the elements of Islamic Religious Education teachers' independence in improving performance both in noble mandate and accountability in aspects of the task. This is confirmed based on the Anderos (Khalili, 2005) assumption, which explains that a person's creativity is a manifestation of independence, namely the process that an individual goes through during his experience and causes him to develop himself.

The results showed that out of 67 elementary school Islamic religious education teachers, the average completeness of the learning planning documents was 12.51 out of a maximum score of 15 . This is comparable to the average quality of Islamic Education, 83.4, which indicates very good.

Because $t$ count is greater than $t$ table $(2,093)$, it can be interpreted that there is a significant increase in the learning planning ability of Islamic Religious Education teachers compared to the initial results during the online performance appraisal. This success can be interpreted as Islamic Religious Education teachers' pedagogical competence in lesson planning shows promising results. This is the initial stage of the development of the Sustainable Professional Development of Islamic Religious Education teachers aimed at the agreed Islamic Religious Education. Likewise, the Sustainable Professional Development program's success rate can be analyzed by confirming Sustainable Professional Development goals. The Sustainable Professional Development program, following the expected development, has not all achieved satisfactory results of Islamic Religious Education. Indicators of success include an increase in the competence and performance of Islamic Religious Education Teachers in a measured, systematic, and sustainable manner. This increase is especially in learning planning, improving the quality of Islamic Religious Education Learning following the supervisor's academic supervision performance. Besides, there is the prevention of understanding radical Islam and the Mental Revolution Movement (Strengthening Character Education in Islamic Religious Education). Increasing understanding of 21st-century learning is also an important thing. The implementation of the mapping of Islamic Religious Education Teacher Skills in Sukabumi City has helped develop a quality assessment and monitoring process of the results of the preparation and tiered teacher education for Islamic Religious Education Teachers.

This research product offers ideas about Sustainable Professional Development. The first stage, the Sustainable Professional Development Model, begins with a self-evaluation. Second, the Islamic Religious Education Supervisor prepares teacher profiles based on the initial Islamic Religious Education caPs. The third stage is developing a Sustainable Professional Development planning program for Islamic Religious Education teachers with several stages of training. Researchers plan Pedagogic Training 1 (Learning Planning), Pedagogic Training 2 (Learning Model), Pedagogic Training 3 (Learning Assessment), Professional Training 1 (Deepening of the Essential Material of Islamic Religious Education), Pedagogic Training 2 (Scientific Publications), Pedagogic Training 3 (Innovative Work), Social and Personality Training, and Spiritual and Leadership Training. The fourth stage, the implementation of the Sustainable Professional Development of Islamic Religious Education, follows the achievement of the initial assessment, which describes the Islamic Religious Education teacher's profile. In the fifth stage, the Islamic Religious Education supervisor evaluates the implementation of Sustainable Professional Development.

Understanding of the factual competency development of teachers Sustainable Professional Development is developed into a conceptual model. The conceptual model in question is given several essential points-first, the problem assumption. Second, problem-solving. Third, an explanation of the design of the Sustainable Professional Development model for Islamic Religious Education. Fourth, development results.

The assumption of the problem contains several issues related to the Sustainable Professional Development of Islamic Religious Education. These problems include: 1) Weaknesses of teacher competence in compiling scientific papers in the form of scientific publications; 2) the manifestation of low professional competence; 3) Weak teacher performance; 4) Continuous professional development has not shown maximum results; 5) Weaknesses in the development of learning as an aspect of pedagogical competence; 5) Low teacher motivation and creativity; 6) So far, training activities or programs organized by the government and those carried out independently of teachers regarding Classroom action research for teachers are still lacking; 7) Classroom Action Research trainings for teachers carried out so far are still dominant at the level of theory or concept, not many are practical; 8) The results of training generally have not had a direct impact on the ability and productivity of teachers in conducting CAR; 9) The training has 
not yet reached the production of the PTK report; 10) There is no follow-up after the training; 11) The ineffective development of the Education and Culture Office, Teacher Working Group/Subject Teacher Council, and the school in managing and implementing Sustainable Professional Development for teachers.

Problem-solving is done employing research and development. The form of problem-solving is designing a Sustainable Professional Development model of Islamic Religious Education. The design of the Sustainable Professional Development model for Islamic Religious Education begins with planning, organizing, implementing, controlling, and evaluating. The development of this model is expected to become a prototype for increasing the competence of Islamic Religious Education teachers.

The explanation above, which is a discussion of the research results, confirms several assumptions of the research's significance. First, the Sustainable Professional Development of Islamic Religious Education teachers must be implemented following the needs analysis in self-evaluation and competency distribution. Second, the Sustainable Professional Development of Islamic Religious Education teachers is directed at increasing professionalism, which is carried out in stages with a planned training design. Third, the Sustainable Professional Development of Islamic Religious Education teachers can be successful if there is some positive support from several stakeholders such as school principals, supervisors of Islamic Religious Education, Teacher Expertise Group and Subject Teacher Council, and elements of the government bureaucracy.

The success rate of the Sustainable Professional Development program can be analyzed through the confirmation of the goals of Sustainable Professional Development. This program is in accordance with the expected development. Not all of them have achieved satisfactory results of Islamic Religious Education. This program takes a long time and involves a variety of quality improvement stakeholders. However, even so, there are several levels of success, including:

a. There is an increase in the competence and performance of Islamic Religious Education Teachers in a measured, systematic, and sustainable manner, especially in learning planning.

b. They are increasing the quality of Islamic Education Learning following the academic supervision performance of supervisors.

c. There is inserting the deterrence of understanding radical Islam and the Mental Revolution Movement (Strengthening Character Education in Islamic Religious Education).

d. Increased understanding of 21st-century learning.

e. Realization of the competency mapping at the level of Sukabumi City of Islamic Religious Education educators.

f. The creation of a process of evaluation and Quality Control of Islamic Education Teacher Training Results in stages.

One of the successes in developing this learning plan is supported by the implementation of the academic supervision of the Islamic Religious Education supervisor. The reality in the field shows that several factors drive the success of one of the Sustainable Professional Development activities, namely teacher training, including creating harmonious relationships, analyzing needs, developing strategies and media, assessing, and revising.

The first step in fostering teacher learning skills is to create a harmonious relationship between supervisors and teachers and all parties related to the development program. It is necessary to have clarity of information among related personnel. To carry out academic supervision. Without clarity of information, teachers will be confused, do not know what the Principal expects, and believe that the main objective in measuring teacher ability, as the first step in coaching learning skills through academic supervision, is only to identify good and less skilled teachers in teaching. However, if there were clarity of information, such teachers would not have happened.

Communication between the Principal and the teacher is said to be useful if the teacher receives academic supervision to develop his / her abilities. In this effort, it is necessary to have clarity of information regarding academic supervision's nature and purpose. To clarify the academic supervision program, specific methods and principles of communication are needed.

Analysis of needs is an attempt to assess the difference between the expertise, abilities, and behaviors needed and those possessed. The theory of rational oversight means that the preparation of a curriculum for teaching supervision must be based on the actual needs of teachers' professional learning. To follow this concept, it is essential to establish a needs review of teacher teaching skills by teaching supervision. The steps to analyze needs are as follows.

a. Identify educational needs or problems - what gaps exist between the knowledge, skills, and attitudes teachers have and what teachers should have? Differences in groups, synthesized and classified.

b. Identify the environment and its constraints.

c. Set long-term general goals. 
d. Identify the management tasks required for this phase, such as finance, resources, equipment, and media.

e. Record procedures for gathering additional information about the teacher's knowledge, skills, and attitudes. Use specific techniques, such as inviting consultants from outside the school/madrasah, interviews, and questionnaires.

f. They are identifying and recording the special needs of teacher learning skills development. Use behavioral or performance words.

g. Determine the needs for teacher learning skills development that can be fostered through techniques and media other than Education.

h. Record and code the needs for teacher learning skills coaching that will be fostered through other means.

Assessment is a systematic process to determine the level of success achieved. In academic supervision, assessment is a systematic process to determine the level of success achieved by Islamic Religious Education in developing teacher learning skills. The objectives of the assessment of learning skills coaching are to (1) determine whether the teacher (teacher) has met the Islamic Religious Education measurement criteria as stated in the coaching objectives, and (2) to determine the validity of the coaching technique and its components in order to improve the next coaching process

The basic principle in designing and implementing an assessment program is that the assessment must measure the performance or behavior specified in teacher academic supervision's objectives. The steps taken are as follows: explaining the assessment techniques, setting objectives, developing measurement instruments that can effectively assess the specified results, conducting field tests to determine their validity, and organizing, analyzing, and summarizing the results.

The final stage is the revision. This activity is carried out as necessary, in accordance with the results of the assessment that has been carried out. The steps taken are as follows. First, reviewing the summary of the assessment results. Second, if it turns out that Islamic Religious Education has not compromised the aim of developing teacher teaching skills, it is better to reassess teachers' knowledge, skills, and attitudes, which are the objectives of the guidance. Third, if it turns out that Islamic Religious Education has not prejudiced the goal, then start by redesigning the teacher's academic supervision program for the next term. Fourth, implementing coaching programs that have been redesigned for the next future.

\section{CONCLUSIONS}

The significant conclusion of this study shows that Sustainable Professional Development can increase the competence of Islamic Education Teachers. The program is designed to improve the competence and performance of Islamic Education Teachers in a measured, systematic, and sustainable manner. The results of this study corroborate Hermawan Kertajaya's theory of "growth with a character," namely characterbased development, by dynamizing the three pillars of the main characters, namely excellence, strong will, and ethics. The professionalism built is strengthened by the Asian Institute for Teachers Education theory about teacher professional competence.

\section{REFERENCES}

Dasuki, A. (2010). Pengembangan Profesionalisme Guru. Manajerial: Jurnal Manajemen Dan Sistem Informasi, 9(2), 1-9.

Gall, M. D., Borg, W. R., \& Gall, J. P. (1996). Educational research: An introduction. Longman Publishing.

Gay, L. R. (1980). Educational Evaluation \& Measurement: Competencies for analysis and application. Merrill Publishing Company.

Khalili, A. A.-S. (2005). Mengembangkan Kreativitas Anak. Pustaka Al-Kautsar.

Mabry, K. (1981). Educatıonal-Evaluatıon And Measurement-Competencies For Analysıs And ApplicationGay, Lr. Amer Personnel Guidance Assn 2 Skylıne Place-Suite 4005203 Leesburg Pıke ....

PITA, A. (2018). REKONSTRUKSI PENDIDIKAN ISLAM (Studi Pemikiran Pendidikan Islam Prof. Dr. Muhaimin, MA). Universitas Muhammadiyah Ponorogo.

Sudjana, N. (2000). Metode penelitian pendidikan. Bandung: UPI [Universitas Pendidikan Indonesia] Press. 